\title{
METODE QUICK COUNT DAN ANALISIS AUTOKORELASI SPASIAL MENGGUNAKAN INDEKS MORAN (STUDI KASUS: PEMILIHAN PRESIDEN INDONESIA TAHUN 2019 DI KALIMANTAN TIMUR)
}

\author{
Riska Veronika ${ }^{1}$, Memi Nor Hayati ${ }^{2}$, Ika Purnamasari ${ }^{3}$ \\ ${ }^{1}$ Mahasiswa Program Studi Statistika, FMIPA, Universitas Mulawarman \\ ${ }^{2}$ Laboratorium Statistika Terapan, Program Studi Statistika, FMIPA, Universitas Mulawarman \\ ${ }^{3}$ Laboratorium Ekonomi dan Bisnis, Program Studi Statistika, FMIPA, Universitas Mulawarman \\ Email: riskaveronika.rv@gmail.com
}

\begin{abstract}
Quick count is a quick caculation method based on sampling that is used to show the results of the temporary vote before the official election results are published. Votes can be influenced by party bases in various regions, so the linkage of the results of vote acquisition between regions needs to be taken into account. Spatial autocorrelation is the correlation between variables and themselves based on space or region. This research has a goal to determine the difference between the results of the estimated vote acquisition using the quick count method with the results of the KPU vote and spatial autocorrelation using the Moran index to determine whether or not there is a spatial autocorrelation of the results of the vote acquisition in the presidential election. The data used is the vote acquisition data of each pair of presidential candidates in the 2019 Indonesian presidential election in East Kalimantan Province using stratified random sampling. The results of the difference between the estimated votes obtained by the quick count method and the KPU calculation is relatively small at $0.01 \%$ and from the results of the spatial autocorrelation test hypothesis it is known that there is no spatial autocorrelation of the results of the vote acquisition for each pair of Indonesian presidential candidates in 10 districts/cities in East Kalimantan in 2019.
\end{abstract}

Keywords: Spatial Autocorrelation, Moran Index, Quick Count, Stratified Random Sampling.

\section{PENDAHULUAN}

Pemilihan di wilayah Indonesia yang sangat luas dan banyak daerah yang sulit dijangkau menyebabkan hasil perolehan suara membutuhkan waktu yang lama. Proses pemungutan suara pada pemilu presiden diadakan serentak di seluruh Indonesia. Setelah proses pemungutan suara selesai, diadakan proses penghitungan suara di seluruh TPS di Indonesia. Rekapitulasi resmi yang dilakukan oleh KPU biasanya memakan waktu hingga tiga minggu. Hal tersebut disebabkan oleh banyaknya data yang harus dikumpulkan dari seluruh wilayah di Indonesia. Melihat lamanya hasil rekapitulasi resmi yang dilakukan oleh KPU, diadakanlah proses perhitungan cepat untuk mendapatkan hasil sementara dari pemilu yang telah diselenggarakan. Proses perhitungan cepat inilah yang biasa disebut sebagai quick count [1].

Quick count dalam dunia ilmu statistik bukan merupakan hal yang baru. Namun, menjadi topik yang perlu untuk diperbincangkan karena keakuratan data yang nantinya dapat digunakan untuk menyajikan infomasi dengan ketepatan yang tinggi. Sehingga, masyarakat berpendapat bahwa perhitungan cepat adalah sebagai cara tepat dan cepat untuk digunakan dalam menentukan siapa yang 
menang atau kalah dalam proses pemilihan umum atau pemilihan kepala daerah [2].

Hasil quick count menimbulkan persepsi dari basis partai yang ada di berbagai wilayah di Indonesia. Basis partai dalam suatu wilayah bisa menjadi tolak ukur kemenangan pemilu di wilayah tersebut. Salah satu metode statistika yang digunakan untuk analisis wilayah adalah statistika spasial. Keterkaitan antara wilayah satu dengan wilayah lainnya bisa diketahui dengan menggunakan autokorelasi spasial [3].

Berdasarkan Hukum Tobler, mengemukakan bahwa sesuatu yang letaknya lebih dekat akan mempunyai hubungan yang lebih besar dibandingkan dengan yang letaknya lebih jauh [4]. Menurut [3], autokorelasi spasial merupakan ukuran kemiripan objek di dalam suatu ruang, baik jarak, waktu, atau wilayah. Menurut [5], autokorelasi spasial suatu variabel menunjukkan bahwa variabel tersebut menunjukkan nilai variabel di daerah tertentu terkait oleh variabel itu pada lokasi lain yang berdekatan.

Besaran autokorelasi spasial dapat digunakan untuk mengidentifikasi hubungan spasial. Untuk mengukur autokorelasi spasial dapat menggunakan indeks Moran. Indeks Moran merupakan salah satu alat yang dapat digunakan untuk menganalisis keterkaitan spasial di segala macam bidang kajian. Indeks Moran merupakan ukuran dari korelasi (hubungan) antara pengamatan yang saling berdekatan. Metode ini membandingkan nilai pengamatan di suatu daerah dengan nilai pengamatan di daerah lainnya [6].

Dari hal yang diuraikan di atas, maka penulis tertarik untuk melakukan penelitian tentang "Metode Quick Count dan Analisis Autokorelasi Spasial Menggunakan Indeks Moran (Studi Kasus: Pemilihan Presiden Indonesia Tahun 2019 di Kalimantan Timur)".

\section{METODOLOGI PENELITIAN}

\section{Sumber Data dan Variabel Penelitian}

Data yang digunakan dalam penelitian ini adalah data sekunder yang diperoleh dari web resmi KPU pilpres Indonesia tahun 2019. Variabel yang digunakan dalam penelitian ini adalah banyaknya suara masing-masing pasangan calon presiden tiap kabupaten/kota di Kalimantan Timur pada pilpres Indonesia tahun 2019 yang diperoleh dengan metode stratified random sampling.

\section{Metode Analisis \\ Metode Quick Count}

Tahapan dari metode quick count dalam penelitian ini adalah sebagai berikut:

1.Menentukan ukuran sampel

$$
n=\frac{\sum_{j=1}^{m} \frac{N_{j}{ }^{2} s_{j} q_{j}}{w_{j}}}{N^{2} D+\sum_{j=1}^{m} N_{j} s_{j} q_{j}}
$$

2.Menghitung alokasi besarnya anggota sampel pada setiap strata

$$
n_{j}=\left[\frac{N_{j}}{\sum_{j=1}^{m} N_{j}}\right] n
$$

3.Memilih sampel TPS setiap strata secara acak menggunakan software Microsoft Excel sesuai dengan besarnya anggota sampel tiap strata.

4.Menghitung perolehan suara tiap pasangan calon presiden Indonesia tahun 2019 di Kalimantan Timur berdasarkan sampel TPS yang terpilih.

5.Menghitung taksiran proporsi tiap pasangan calon pilpres Indonesia tahun 2019 di Kalimantan Timur.

$$
\hat{p}_{k}=\frac{1}{y} \sum_{j=1}^{m} y_{k j}, \text { dimana } \mathrm{k}=1,2, \ldots, \mathrm{L}
$$

6.Menghitung besarnya kesalahan sampling. 


$$
K S=|\hat{p}-p|
$$

7. Menyimpulkan hasil analisis.

\section{Autokorelasi Spasial}

Adapun tahapan dari autokorelasi spasial dengan indeks Moran adalah sebagai berikut:

1.Membuat peta persebaran hasil perolehan suara dari KPU tiap pasangan calon pilpres Indonesia tahun 2019 pada 10 kabupaten/kota di Kalimantan Timur.

2.Menentukan kedekatan antar kabupaten/kota di Kalimantan Timur dengan membuat matriks contiguity. Untuk penentuan kedekatan antar kabupaten/kota ini alat yang digunakan adalah peta Kalimantan Timur dan cara yang digunakan dalam penentuan kedekatan menggunakan queen contiguity berukuran $10 \times 10$ sesuai dengan banyaknya kabupaten/kota di Kalimantan Timur.

3.Menghitung matriks pembobot spasial yang diperoleh dari matriks contiguity yang nantinya akan membentuk sebuah matriks yang telah distandarisasi.

$$
w_{i j}=\frac{c_{i j}}{c_{i \bullet}}
$$

4.Mencari nilai statistik indeks Moran.

$$
I=\frac{\sum_{i=1}^{m} \sum_{j=1}^{m} w_{i j}\left(x_{i}-\bar{x}\right)\left(x_{j}-\bar{x}\right)}{\sum_{i=1}^{m}\left(x_{i}^{2}-\bar{x}^{2}\right)}
$$

5.Melakukan uji hipotesis dari nilai statistik uji indeks Moran, kemudian membuat Moran's Scatterplot.

$$
Z_{\text {hitung }}=\frac{I-E(I)}{\sqrt{\operatorname{Var}(I)}}
$$

6.Menyimpulkan hasil analisis.

\section{HASIL PENELITIAN}

\section{Metode Quick Count}

Berikut akan dijelaskan langkahlangkah perhitungan metode quick count menggunakan stratified random sampling:

\section{Ukuran Sampel Keseluruhan}

Pada metode quick count dengan menggunakan stratified random sampling, tahap awal menghitung terlebih dahulu banyak sampel keseluruhan di Kalimantan Timur menggunakan persamaan (1). Sehingga didapat banyaknya sampel secara keseluruhan adalah sebagai berikut:

$$
\begin{aligned}
n & =\frac{\frac{703^{2} \times 0,5 \times 0,5}{0,064}+\frac{2.055^{2} \times 0,5 \times 0,5}{0,188}+\ldots+\frac{515^{2} \times 0,5 \times 0,5}{0,047}}{\left(10.908^{2} \times 0,000025\right)+\left(703 \times 0,5 \times 0,5+2.055^{2} \times 0,5 \times 0,5+\ldots+515^{2} \times 0,5 \times 0,5\right)} \\
& =5.217,142 \approx 5.217 \mathrm{TPS}
\end{aligned}
$$

\section{Ukuran Sampel Tiap Strata}

Setelah mendapatkan sampel keseluruhan langkah selanjutnya adalah menghitung sampel tiap strata dengan menggunakan persamaan (2). Strata pada penelitian ini adalah 10 kabupaten/kota di Kalimantan Timur.

Setelah diperoleh jumlah sampel TPS yang dibutuhkan tiap strata, selanjutnya dilakukan pengambilan sampel secara acak tanpa pengembalian pada tiap strata.

\section{Taksiran Proporsi Pasangan Calon}

Dari sampel-sampel TPS yang terpilih maka dihitung proporsi hasil perolehan suara tiap pasangan calon dengan persamaan (3).

Tabel 1. Proporsi Hasil Perolehan Suara tiap Pasangan Calon Berdasarkan Sampel TPS

\begin{tabular}{c|l|c|c}
\hline No & $\begin{array}{l}\text { Nama Pasangan Calon } \\
\text { Presiden }\end{array}$ & $\begin{array}{c}\text { Taksiran } \\
\text { Proporsi }\end{array}$ & $\begin{array}{c}\text { Dalam } \\
\text { Persentase }\end{array}$ \\
\hline 1 & Jokowi-Ma'ruf Amin & 0,5567 & $55,67 \%$ \\
2 & Prabowo-Sandiaga Uno & 0,4433 & $44,33 \%$ \\
\hline
\end{tabular}

Dari Tabel 1 dapat diketahui bahwa hasil taksiran proporsi untuk pasangan calon 01 lebih besar dari pasangan calon 02 yang menunjukkan bahwa hasil perolehan suara dimenangkan oleh pasangan calon 01 berdasarkan perhitungan menggunakan metode quick count.

Membandingkan dengan Hasil Perhitungan Suara KPU

Tabel 2. Proporsi Hasil Perolehan Suara tiap \begin{tabular}{l|l|c}
\multicolumn{3}{c}{ Pasangan Calon Berdasarkan Hasil KPU } \\
\hline No & Nama Pasangan Calon & Dalam Persentase \\
& Presiden & $55,68 \%$ \\
\hline 1 & Jokowi-Ma'ruf Amin & $44,32 \%$ \\
2 & Prabowo-Sandiaga Uno & \\
\hline
\end{tabular}

Berdasarkan hasil perhitungan suara pada Tabel 2, kita dapat mengetahui selisih persentase antara hasil suara dari KPU 
dengan persentase hasil perolehan suara berdasarkan metode quick count.

Tabel 3.Selisih Persentase antara Hasil Perolehan

\begin{tabular}{l|l|c}
\multicolumn{3}{c}{ Suara dari KPU dengan Metode Quick Count } \\
\hline No & $\begin{array}{l}\text { Nama Pasangan Calon } \\
\text { Presiden }\end{array}$ & $|p-\hat{p}|$ \\
\hline 1 & Jokowi-Ma'ruf Amin & $0,01 \%$ \\
2 & Prabowo-Sandiaga Uno & $0,01 \%$ \\
\hline
\end{tabular}

Dari Tabel 3 diketahui bahwa selisih taksiran proporsi dari metode Quick Count dengan perhitungan KPU relatif kecil, yaitu $0,01 \%$.

\section{Autokorelasi Spasial}

Sebelumnya telah dijelaskan langkahlangkah dalam metode quick count, selanjutnya analisis autokorelasi spasial untuk mengetahui apakah terdapat hubungan spasial hasil perolehan suara tiap pasangan calon presiden di 10 kabupaten/kota di Kalimantan Timur.

\section{Peta Tematik}

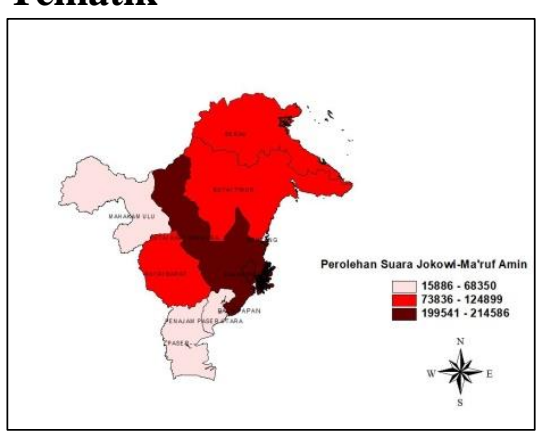

Gambar 1. Peta tematik hasil perolehan suara pasangan calon nomor urut 01 (Jokowi-Ma'ruf Amin) pada pilpres Indonesia tahun $2019 \mathrm{di}$

Kalimantan Timur berdasarkan hasil KPU

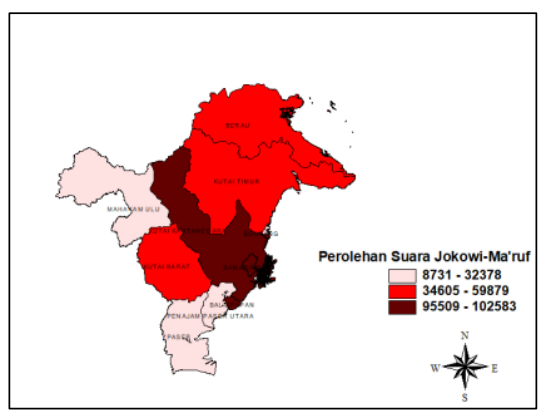

Gambar 2. Peta tematik hasil perolehan suara pasangan calon nomor urut 01 (Jokowi-Ma'ruf Amin) pada pilpres Indonesia tahun 2019 di Kalimantan Timur berdasarkan hasil sampling

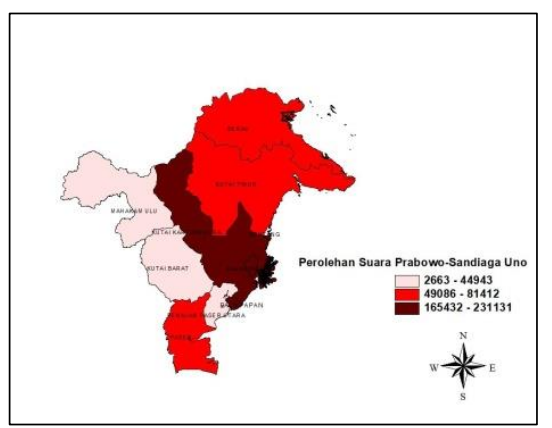

Gambar 3. Peta tematik hasil perolehan suara pasangan calon nomor urut 02 (Prabowo-Sandiaga

Uno) pada pilpres Indonesia tahun $2019 \mathrm{di}$

Kalimantan Timur berdasarkan hasil KPU

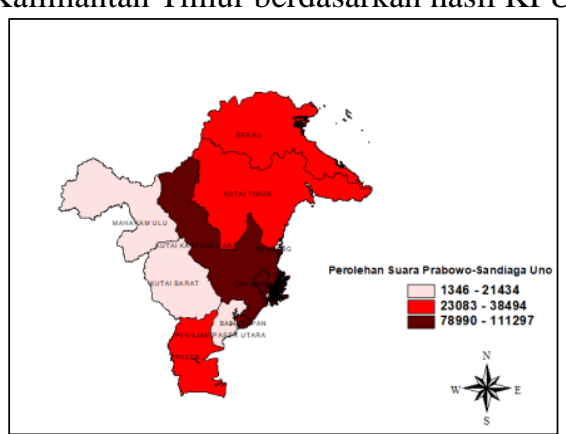

Gambar 4. Peta tematik hasil perolehan suara pasangan calon nomor urut 02 (Prabowo-Sandiaga

Uno) pada pilpres Indonesia tahun 2019 di

Kalimantan Timur berdasarkan hasil sampling

\section{Nilai Indeks Moran Pasangan Calon 01}

Tabel 4 menunjukkan hasil perhitungan indeks Moran untuk pasangan calon presiden nomor urut 01 (Jokowi-Ma'ruf Amin) berdasarkan persamaan (6).

Tabel 4. Nilai Indeks Moran Pasangan Calon Presiden Nomor Urut 01 (Jokowi-Ma'ruf Amin)

\begin{tabular}{c|c|c}
\hline Pendekatan & Indeks Moran & Identifikasi \\
\hline Queen contiguity & 0,136 & $\begin{array}{c}\text { Autokorelasi } \\
\text { positif }\end{array}$ \\
\hline
\end{tabular}

\section{Nilai Indeks Moran Pasangan Calon 02}

Tabel 5 menunjukkan hasil perhitungan indeks Moran untuk pasangan calon presiden nomor urut 02 (Prabowo-Sandiaga Uno) berdasarkan persamaan (6).

Tabel 5. Nilai Indeks Moran Pasangan Calon Presiden Nomor Urut 02 (Prabowo-Sandiaga Uno)

\begin{tabular}{c|c|c}
\hline Pendekatan & Indeks Moran & Identifikasi \\
\hline Queen contiguity & 0,245 & $\begin{array}{c}\text { Autokorelasi } \\
\text { positif }\end{array}$ \\
\hline
\end{tabular}




\section{Uji Hipotesis Kedua Pasangan Calon Presiden}

Sebelumnya telah diperoleh nilai indeks Moran hasil perolehan suara pasangan calon 01 dan 02 tahun 2019 di Kalimantan Timur berada pada rentang $0<I \leq 1$ maka menggunakan $H_{1}$ (hipotesis alternatif) indeks Morans bersifat positif. Pengujian hipotesis dari pemeriksaan autokorelasi spasial disajikan sebagai berikut:

$H_{0}$ : Tidak terdapat autokorelasi spasial atau tidak terdapat hubungan hasil perolehan suara antar kabupaten/kota di Kalimantan Timur pada pilpres Indonesia tahun 2019

$H_{1}$ : Terdapat autokorelasi spasial atau terdapat hubungan hasil perolehan suara antar kabupaten/kota di Kalimantan Timur pada pilpres Indonesia tahun 2019

Tabel 6 menunjukkan hasil pengujian indeks Moran dimana nilai $Z_{\text {hitung }}$ dibandingkan dengan $Z_{0,025}=1,96$.

Tabel 6. $Z_{\text {hitung }}, Z_{\alpha / 2}$, dan Keterangan Pasangan Kedua Pasangan Calon Presiden

\begin{tabular}{c|c|c|c}
\hline $\begin{array}{c}\text { Pasangan Calon } \\
\text { Presiden }\end{array}$ & $\left|Z_{\text {hitung }}\right|$ & $Z_{0,05 / 2}$ & Keterangan \\
\hline $\begin{array}{c}\text { Jokowi-Ma'ruf } \\
\text { Amin } \\
\begin{array}{c}\text { Prabowo- } \\
\text { Sandiaga Uno }\end{array}\end{array}$ & 1,05 & 1,96 & $\begin{array}{c}\text { Gagal menolak } \\
\mathrm{H}_{0}\end{array}$ \\
\hline
\end{tabular}

Dari Tabel 6 disimpulkan bahwa dengan pendekatan queen contiguity diketahui bahwa tidak terdapat autokorelasi spasial atau tidak terdapat hubungan hasil perolehan suara tiap pasangan calon presiden Indonesia pada 10 kabupaten/kota di Kalimantan Timur tahun 2019.

Dapat dilihat pada Gambar 5 perolehan suara pasangan calon presiden nomor urut 01 (Jokowi-Ma'ruf Amin) yang berada pada Kuadran I yaitu Kota Samarinda dan Kota Balikpapan yang menunjukkan bahwa Kota Samarinda dan Kota Balikpapan memiliki perolehan suara yang tinggi dan dikelilingi oleh kabupaten/kota yang memiliki perolehan suara yang tinggi juga. Kabupaten/kota yang berada pada Kuadran II yaitu Kota Bontang, Kabupaten Mahakam Ulu, dan Kabupaten Penajam Paser Utara yang menunjukkan bahwa kabupaten/kota tersebut memiliki perolehan suara yang rendah dan dikelilingi oleh kabupaten/kota yang memiliki perolehan suara tinggi. Kabupaten yang berada pada Kuadran III yaitu Kabupaten Berau, Kabupaten Kutai Barat, dan Kabupaten Paser yang menunjukkan bahwa kabupaten tersebut memiliki perolehan suara yang rendah dan dikelilingi oleh kabupaten/kota yang memiliki perolehan suara yang rendah juga. Kabupaten yang berada pada Kuadran IV yaitu Kabupaten Kutai Kartanegara dan Kabupaten Kutai Timur yang menunjukkan bahwa kabupaten tersebut memiliki perolehan suara yang tinggi dan dikelilingi oleh kabupaten/kota yang memiliki perolehan suara rendah.

Pada Gambar 6 perolehan suara pasangan calon presiden nomor urut 02 (Prabowo-Sandiaga Uno) yang berada pada Kuadran I yaitu Kota Samarinda dan Kota Balikpapan yang menunjukkan bahwa Kota Samarinda dan Kota Balikpapan memiliki perolehan suara yang tinggi dan dikelilingi oleh kabupaten/kota yang memiliki perolehan suara yang tinggi juga. Kabupaten/kota yang berada pada Kuadran II yaitu Kota Bontang, Kabupaten Mahakam Ulu, dan Kabupaten Penajam Paser Utara yang menunjukkan bahwa kabupaten/kota tersebut memiliki perolehan suara yang rendah dan dikelilingi oleh kabupaten/kota yang memiliki perolehan suara tinggi. Kabupaten yang berada pada Kuadran III yaitu Kabupaten Berau, Kabupaten Kutai Barat, Kabupaten Kutai Timur dan Kabupaten Paser yang menunjukkan bahwa kabupaten tersebut memiliki perolehan suara yang rendah dan dikelilingi oleh kabupaten/kota yang memiliki perolehan suara yang rendah juga. Kabupaten yang berada pada Kuadran IV 
yaitu Kabupaten Kutai Kartanegara yang menunjukkan bahwa kabupaten tersebut memiliki perolehan suara yang tinggi dan dikelilingi oleh kabupaten/kota yang memiliki perolehan suara rendah.

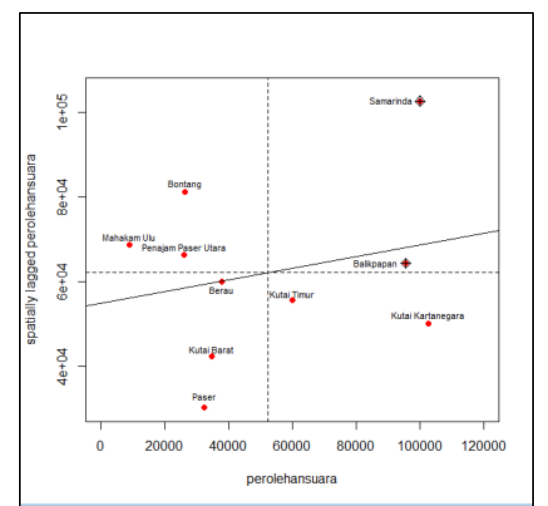

Gambar 5. Moran's scatterplot perolehan suara pasangan calon presiden nomor urut 01 (JokowiMa'ruf Amin)

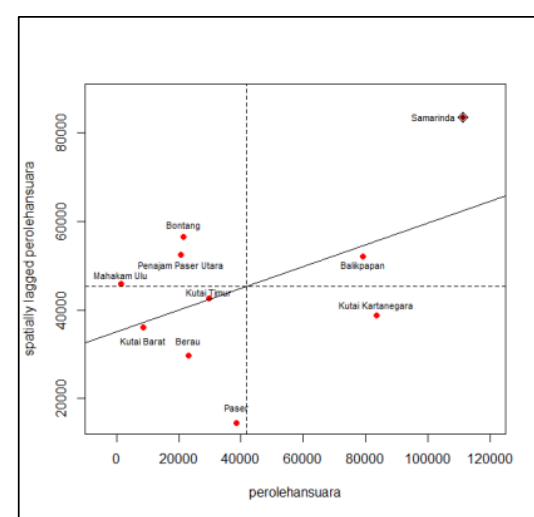

Gambar 6. Moran's scatterplot perolehan suara pasangan calon presiden nomor urut 02 (Prabowo-Sandiaga Uno)

\section{KESIMPULAN}

Berdasarkan hasil analisis data dan pembahasan, diperoleh kesimpulan sebagai berikut:

1. Hasil metode quick count menggunakan teknik stratified random sampling dengan margin of error sebesar $1 \%$ diketahui bahwa selisih taksiran perolehan suara dari metode quick count dengan perhitungan KPU Samarinda relatif kecil, yaitu $0,01 \%$.

2. Hasil hipotesis indeks Moran dengan pendekatan queen contiguity diketahui bahwa tidak terdapat autokorelasi spasial atau tidak terdapat hubungan hasil perolehan suara tiap pasangan calon presiden di 10 kabupaten/kota di Kalimantan Timur tahun 2019.

\section{UCAPAN TERIMA KASIH}

Penulis mengucapkan terima kasih kepada KPU yang telah menyediakan data dan kepada Laboratorium Statistika Terapan FMIPA Universitas Mulawarman sebagai tempat pengolahan data.

\section{DAFTAR PUSTAKA}

[1] Desvira, D. (2014). Penerapan Algoritma Greedy dalam Menentukan Sampel TPS pada Quick Count. Makalah IF2211 Strategi Algoritma. Bandung: Institut Teknologi Bandung.

[2] Ulya, S. F., Sukestiyarno Y. L., dan Hendikawati P. (2018). Analisis Prediksi Quick Count dengan Metode Stratified Random Sampling dan Estimasi Confidence Interval Menggunakan Metode Maksimum Likelihood. UNNES Journal of Mathematics 7(1): 108-119.

[3] Prahutama, A. (2014). Analisis Kemenangan Pemilihan Gubernur (PILGUB) Jawa Tengah 2013 dengan Autokorelasi Spasial. Jurnal Statistika, Vol 2, No. 1, Halaman 6-12.

[4] Anselin, L. (1993). Exprolatory Spatial Data Analysis and Geographic Information System. California Santa Barabara: National Center for Geographic Information and Analysis.

[5] Anselin, L. (1988). Spatial Econometrics: Methods and Models. London: Kluwer Academic Publisher.

[6] Syafitri, Utami, D., Bagus S. dan Salamatuttanzil. (2008). Pengujian Autokorelasi terhadap Sisaan Model Spatial Logistik. Seminar Nasional Matematika dan Pendidikan Matematika, Halaman: 2. Bogor: FMIPA IPB. 